\title{
Geochemistry of volcanic fluids
}

\section{A special issue of the Bulletin of Volcanology in honour of Yuri A. Taran}

\author{
Salvatore Inguaggiato $\cdot$ Hiroshi Shinohara $•$ \\ Tobias Fischer
}

Received: 7 October 2010 /Accepted: 11 December 2010 / Published online: 17 May 2011

(C) Springer-Verlag 2011

This special issue is dedicated to Yuri Taran's outstanding contributions to gas geochemistry that began in the early 1980 s with his work on deuterium and ${ }^{18} \mathrm{O}$ compositions of geothermal waters in the Mutnovsky (Kamchatka) region and continues to this day with work on the Kamchatka volcanic volatile budget, carbon isotopes of hydrocarbons, and new insights into the geochemistry of El Chichón volcano, Chiapas. Yuri has contributed greatly to the field of volcanic gas geochemistry and was the first to recognize the distinct deuterium and oxygen isotopic composition of fumarole condensates from volcanoes in Kamchatka (Taran et al.

Editorial responsibility: J. Stix

This paper constitutes part of a special issue. The complete citation information is as follows:

Inguaggiato S, Shinohara H, Fischer T (2011) Geochemistry of Volcanic Fluids. In: Inguaggiato S, Shinohara H, and Fischer T (eds) Geochemistry of volcanic fluids: a special issue in honor of Yuri A. Taran. Bull Volcanol 73(4):369-372

\author{
S. Inguaggiato $(\bowtie)$ \\ Istituto Nazionale di Geofisica e Vulcanologia, \\ Via Ugo la Malfa 153 \\ 90146 Palermo, Italy \\ e-mail: s.inguaggiato@pa.ingv.it \\ H. Shinohara \\ Geological Survey of Japan, AIST, \\ Central 7, 1-1-1 Higashi, \\ Tsukuba, Ibaraki 305-8567, Japan \\ e-mail: shinohara-h@aist.go.jp \\ T. Fischer \\ Department of Earth and Planetary Sciences, University of New \\ Mexico, \\ Albuquerque, NM 87131-1116, USA \\ e-mail: fischer@unm.edu
}

1987a). The shift in $\delta \mathrm{D}$ and $\delta^{18} \mathrm{O}$ to significantly heavier values compared to local meteoric water led Yuri to introduce the term "andesitic water" (Taran et al. 1989a, b) which has since been recognized at subduction zone volcanoes globally. This distinct isotopic composition is evidence that volcanoes release water that ultimately originates as subducted seawater and is recycled through the mantle wedge back to the earth's surface. Yuri's early work on the gas emissions from Kamchatka and Kurile Islands volcanoes also included the development and testing of gas geothermometers (Taran 1986) and investigating hydrothermal alteration using isotopic data (Taran et al. 1987b). His curiosity remained focused on the isotope systematics of volcanic gases discharging from Kamchatka and the Kuriles through the late 1980s and 1990s with publications on the gas compositions of Klyuchevskoi (Taran et al. 1991), Mutnovsky (Taran et al. 1992), Avachinsky and Koryaksky (Taran et al. 1997). Yuri was involved in the discovery of a pure and unique rhenium mineral on Kudryavy volcano (Korzhinsky et al. 1994) and provided one of the most detailed chemical studies of high temperature (up to $950^{\circ} \mathrm{C}$ ) fumaroles to date of any volcano (Taran et al. 1995). His 1995 paper on Kudryavy remains highly cited and provides the highest quality volcanic gas data which also include trace elements from a subduction zone. Such data are crucial when we attempt to interpret lower temperature volcanic gas compositions or calculate rare metal fluxes from volcanoes worldwide. His most recent publication on Kamchatka-Kurile volcanic emissions provides a detailed analysis of the total gas flux from these volcanoes (Taran 2009).

After leaving the Institute of Volcanic Geology and Geochemistry in Kamchatka in the mid-1990s and moving permanently to the Universidad Nacional Autonoma de Mexico (UNAM), Yuri's already high productivity literally exploded. He discovered a new country and new volcanoes 
with lots of fumaroles and interesting magmatichydrothermal systems as well as a crater lake. Yuri's work on El Chichón provided a comprehensive model of its fascinating sulfur-rich hydrothermal system (Taran et al. 1998) and the dynamics of the crater lake (Rouwet et al. 2008; Taran and Rouwet 2008). His research on crater lakes resulted in several papers with students and colleagues (Capaccioni et al. 2004; Mazot et al. 2007; Mazot and Taran 2009; Taran and Rouwet 2008). He was the first to sample the fumaroles of Everman volcano, Socorro Island, and explained its unique isotope composition and highly reduced gas chemistry (Taran and Cienfuegos 2008; Taran et al. 2002). Together with students he explored the remote Tacana volcano on the Guatemala-Mexico border and first reported the geochemistry of its springs and fumaroles (Rouwet et al. 2009). At Colima, Yuri helped discover a new mineral (Ostrooumov et al. 2009) and showed how elements are transported by highly oxidized gases (GonzalezHernandez and Taran 2005).

Besides being an excellent and rigorous teacher in the field, Yuri has always been firmly grounded in laboratory analyses and theoretical approaches (Osadchii et al. 1997; Taran 2003, 2005; Taran et al. 2007). Yuri's approach to collecting and analyzing samples followed by rigorous and creative interpretation of the results continues to be an inspiration for many scientists working on active volcanic and hydrothermal systems. His continued dedication to the IAVCEI Commission on the Chemistry of Volcanic Gases as president since 2000 is highly valued by the community. We would like to express our greatest appreciation for Yuri's contributions and continued enthusiasm and inspiration by dedicating this volume to him.

The papers in this volume cover a range of topics in volcanic fluid geochemistry that reflect Yuri's interests in volcanology and geochemistry. The papers by Zelenski and Taran discuss the contribution of mantle, slab, and atmospheric contributions to volcanic emissions. Shinohara et al. report spatial and temporal variations of fumarolic gas discharges at Meakan volcano, Japan, and assess the origin of the fumarolic gases formed by interaction of magmatichydrothermal systems. Crater lakes are important sources of volcanic volatile emissions; however, fluxes from crater lakes have been poorly quantified. Mazot et al. conducted intensive $\mathrm{CO}_{2}$ emission rate measurements on and around the crater lake of El Chichón crater lake by applying a floating chamber method. They demonstrate the significant $\mathrm{CO}_{2}$ and $\mathrm{H}_{2}$ emissions through the lake. $\mathrm{CO}_{2}$ and $\mathrm{SO}_{2}$ emissions as indicators of renewed volcanic activity at Stromboli are discussed by Inguaggiato et al. The paper by Ohba et al. examines temporal variations of chemical and isotopic compositions of fumarolic and borehole discharges at Hakone volcano, Japan, particularly in relation to the occurrence of seismic swarms beneath the volcano. They propose that injection of $\mathrm{CO}_{2}$-rich magmatic gases caused the seismic swarm.

\section{References}

Capaccioni B, Taran Y, Macias JL, Tassi F, Vaselli O, Mangani G (2004) Source conditions and degradation processes of light hydrocarbons in volcanic gases: an example from El Chichon volcano (Chiapas State, Mexico). Chem Geol 206:81-96

Gonzalez-Hernandez G, Taran YA (2005) Transport of elements by high-temperature and highly oxidized gases from Colima volcano. Geochim Cosmochim Acta 69:A733

Korzhinsky MA, Tkachenko SI, Shmulovich KI, Taran YA, Steinberg GS (1994) Discovery of a pure rhenium mineral at Kudriavy volcano. Nature 369:51-52

Mazot A, Taran Y (2009) $\mathrm{CO}_{2}$ flux from the volcanic lake of El Chichón (Mexico). Geofis Int 48:73-83

Mazot A, Bernard A, Taran Y (2007) Carbon dioxide degassing and estimation of thermal energy release from volcanic lakes. Geochim Cosmochim Acta 71:A643

Osadchii EG, Lunin SE, Korzhinskii MA, Tkachenko SI, Taran YA (1997) fO(2) and fS(2) measurements by electrochemical sensors in high-temperature fumaroles of active volcanoes. Geokhimiya $1: 74-81$

Ostrooumov M, Taran Y, Arellano-Jimenez M, Ponce A, Reyes-Gasga J (2009) Colimaite, $\mathrm{K}_{3} \mathrm{VS}_{4}$ - a new potassium-vanadium sulfide mineral from the Colima volcano, State of Colima (Mexico). Rev Mex Cienc Geol 26:600-608

Rouwet D, Taran Y, Inguaggiato S, Varley N, Santiago JAS (2008) Hydrochemical dynamics of the "lake-spring" system in the crater of El Chichon volcano (Chiapas, Mexico). J Volcanol Geotherm Res 178:237-248

Rouwet D, Inguaggiato S, Taran Y, Varley N, Santiago JA (2009) Chemical and isotopic compositions of thermal springs, fumaroles and bubbling gases at Tacana Volcano (MexicoGuatemala): implications for volcanic surveillance. Bull Volcanol 71:319-335

Taran YA (1986) Gas geothermometers for hydrothermal systems. Geochem Int 23:111-126

Taran YA (2003) Light hydrocarbons in volcanic and hydrothermal fluids. Geochim Cosmochim Acta 67:A477

Taran YA (2005) A method for determination of the gas-water ratio in bubbling springs. Geophys Res Lett 32:L23403. doi:10.1029/ 2005GL024547

Taran YA (2009) Geochemistry of volcanic and hydrothermal fluids and volatile budget of the Kamchatka-Kuril subduction zone. Geochim Cosmchim Acta 73:1067-1094

Taran Y, Cienfuegos E (2008) Inverse carbon isotopic trend in hydrocarbons from hydrothermal fluids of Socorro Island, Mexico. Geochim Cosmochim Acta 72:A935

Taran Y, Rouwet D (2008) Estimating thermal inflow to El Chichón crater lake using the energy-budget, chemical and isotope balance approaches. J Volcanol Geotherm Res $175: 472-481$

Taran YA, Kirsanova TP, Vakin EA, Esikov AD, Cheshko AL (1987a) Isotopic composition of water of fumarole gases of volcanoes of Kamchatka. Izvestiya Akademii Nauk Sssr Seriya Geologicheskaya 9:124-127

Taran YA, Pokrovsky BG, Glavatskikh SF (1987b) Conditions of hydrothermal alteration of rocks of the Mutnovskaya geothermal system deduced from isotopic data. Geokhimiya 11:15691579 
Taran YA, Pokrovsky BG, Dubik (1989a) Isotopic composition and the origin of water from andesitic magmas. Trans Acad Sci USSR 304:440-443

Taran YA, Pokrovsky BG, Esikov AD (1989b) Deuterium and oxygen-18 in fumarolic steam and amphiboles from some Kamchatka volcanoes: "andesitic waters". Dokl Akad Nauk SSSR 304:440-443

Taran YA, Rozhkov AM, Serafimova EK, Esikov AD (1991) Chemical and isotopic composition of magmatic gases from the 1988 eruption of Klyuchevskoi volcano, Kamchatka. J Volcanol Geotherm Res 46:255-263

Taran YA, Pilipenko VP, Rozhkov AM, Vakin EA (1992) A geochemical model for fumaroles of the Mutnovsky volcano, Kamchatka, USSR. J Volcanol Geotherm Res 49:269-283

Taran YA, Hedenquist JW, Korzhinsky MA, Tkachenko SI, Shmulovich KI (1995) Geochemistry of magmatic gases from Kudriavy volcano, Iturup, Kuril Islands. Geochim Cosmochim Acta 59:1749-1761

Taran YA, Connor CB, Shapar VN, Ovsyannikov AA, Bilichenko AA (1997) Fumarolic activity of Avachinsky and Koryaksky volcanoes, Kamchatka, from 1993 to 1994. Bull Volcanol 58:441-448

Taran Y, Fischer TP, Pokrovsky B, Sano Y, Aurora Armienta M, Macias JL (1998) Geochemistry of the volcano-hydrothermal system of El Chichón volcano, Chiapas, Mexico. Bull Volcanol 59:436-449

Taran YA, Fischer TP, Cienfuegos E, Morales P (2002) Geochemistry of hydrothermal fluids from an intraplate ocean island: Everman volcano, Socorro Island, Mexico. Chem Geol 188:51-63

Taran YA, Kliger GA, Sevastianov VS (2007) Carbon isotope effects in the open-system Fischer-Tropsch synthesis. Geochim Cosmochim Acta 71:4474-4487 